\title{
CREATING AND MAINTAINING A SECURE AND SAFE ENVIRONMENT ON A CHALLENGED CIVILIAN UNIVERSITY CAMPUS IN PAPUA NEW GUINEA
}

\author{
Garry SALI, Mirzi BETASOLO, Eric GILDER \\ University of Technology, Lae, Papua New Guinea \\ garry.sali@pnguot.ac.pg, mirzi.betasolo@pnguot.ac.pg, \\ eric.gilder@pnguot.ac.pg
}

\begin{abstract}
The article introduces the challenges of maintaining effective security (of both personnel and property) on a 220 hectare rural/suburban University campus, The Papua New Guinea University of Technology, located on the outskirts of Lae, the second-largest city in Papua New Guinea, serves as its main port and manufacturing hub. Since the Independence of Papua New Guinea in 1975, the city of Lae, the University (of approximately 3000 students, and 1500 academic, technical, and administrative and staff) and its surrounding communities have faced increasing pressing security issues, some caused by internal (on campus) and others by external (off campus) factors. After a long, politically motivated student boycott in 2016 (which ended up with destruction of varied University properties and the death of a student), the University has endeavoured to create a safe campus environment by employing quantitative modelling predictive techniques, cost-effective technologies and appropriate social-psychological insights aimed at transcending extant tribal mindsets (the country is noted for having over 800 tribes and languages across its widely space geography of $462,840 \mathrm{Km}$ and approximately 7 million population). Tribal conflict is a constant concern for the police and governing authorities, an inhibitor of balanced social and economic development of the resource-rich country.
\end{abstract}

Keywords: Papua New Guinea, PNGUoT/(UNITECH), security, quantitative predictive modelling, crime-fighting technology

\section{Introduction}

\subsection{Geography and Population}

The Independent State of Papua New Guinea (PNG), established 1975, is situated north of Australia (6 $00 \mathrm{~S}, 14700 \mathrm{E})$, on the eastern part of the Indonesian island. It was created by the merger of former German New Guinea (north) and former British Papua (south) in 1902 under Australian administration [1]. Its area size (water and land) is $462,840 \mathrm{sq} \mathrm{km}$ and its present population (2018 estimate) is $7,027,332$, divided into approximately 800 linguistically distinct tribal groups, descended from Micronesian, Melanesian, Papuan, Polynesian, Negrito, origins. Most live in rural areas in the Highlands and Coastal regions [2]. See map for layout and location of the main cities. 


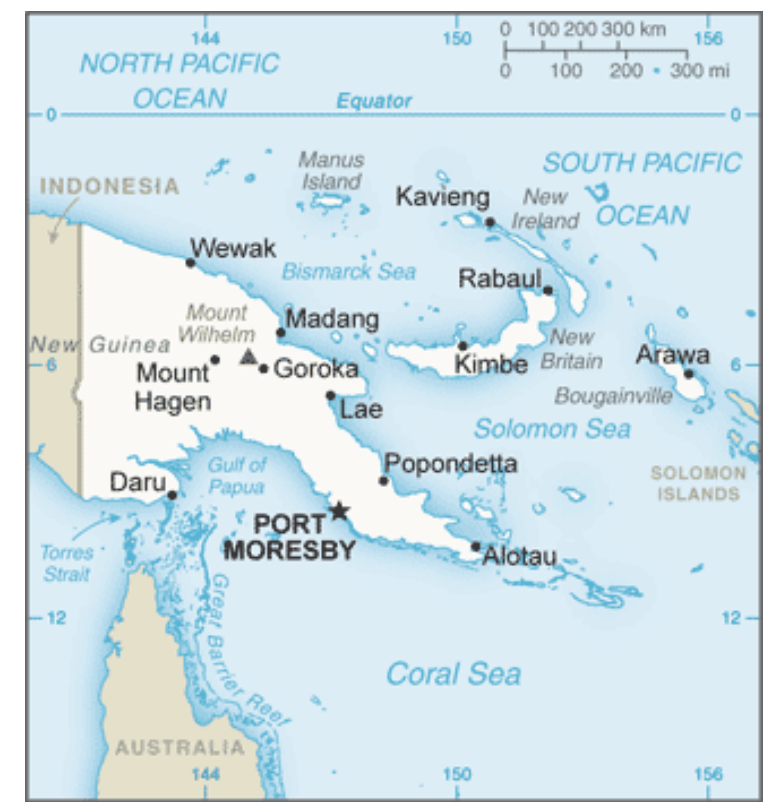

Figure 1: Map of Papua New Guinea (Central Intelligence Agency, 2019).

\subsection{The University and its Locale}

The Papua New Guinea University of Technology (PNGUoT), also known as UNITECH, is a 3000-student University (with about 1500 staff), situated on 220 hectares of land $8 \mathrm{~km}$ outside of Lae, the manufacturing and port city of PNG, population of 100,677 (2012)[3]. It was established in 1965 by a Government Act (when PNG was under Australian governance), along with its 'sister' University of Papua New Guinea, located in the capital, Port Moresby. Having 13 academic departments spread among the Engineering, Sciences, Agriculture/ Forestry, Built Environment, Business and Social Science disciplines, the University seeks to continue to be "the leading innovative, entrepreneurial, and student centered university, contributing to a knowledge based society in PNG and the South Pacific"[4]. To achieve this vision, the University has to effectively deal with many challenges, one of the main ones being issues of security on campus.

\subsection{Security Context in Papua New Guinea and Lae}

Since Independence, PNG has faced increased security problems as (mostly young) people have migrated from largely self-sustaining rural villages to cash-based urban locales and economies [5]. As The CIA's World Factboook notes, "the indigenous population of Papua New Guinea (PNG) is one of the most heterogeneous in the world; PNG has several thousand separate communities, most with only a few hundred people; divided by language, customs, and tradition, some of these communities have engaged in low-scale tribal conflict with their neighbors for millennia; the advent of modern weapons and modern migrants into urban areas has greatly magnified the impact of this lawlessness" [6]. Therefore, the city of Lae and the campus of PNGUoT have been affected by this general trend. As Gully states, "when the university was built [in 1969] it was surrounded by many kilometres of vacant and undeveloped land [. . .] Unfortunately with the passage of time the university is now surrounded by [illegal] settlements and is now threatened by an ever increasing crime rate. In 1991 according to personal records kept by the author the crime rate within Lae was some 22 crimes per 100,000 persons. That figure included Murder, Rape, Robbery and Aggravated Burglary" [7]. The security problem has worsened 
since, with a 2014 World Bank report stating that this increase in "crime and violence are driven in part by recent social and economic changes, which have created disputes that are less amenable to management by traditional means. In particular, violence in PNG can be understood, at least partly, as a result of the inability of both traditional and formal institutions to manage the stresses that have come with rapid economic growth, increasing migration, and other factors" [8].

\subsection{Security Context at PNGUoT/UNITECH}

Unfortunately, the PNGUoT has in its recent history been plagued by inter- and extra-institutional conflict, often marked by boycotts, both peaceful and violent [9]. In 2016, a weeks-long student-led boycott (called over a political dispute about the country's Prime Minister), begun peaceably yet descended into tribal fighting and violence, with a student being killed and University buildings burnt down, and a foreign faculty member being threatened [10]. As a result of this tragedy, the University management had security consultant Graeme G. Gully of Corporate Control Strategies (Australia) perform a risk assessment and risk mitigation strategy advisory study, completed in 2016.

\subsection{Risk Assessment Analysis}

According to Gully, the risk assessment procedure carried out was in furtherance of the following outcomes, that is, increased:

"(i) Security for academic staff travelling to site, from site and within the University Campus. (ii) Security for students when on campus. (iii) Physical security including access control and asset protection. (iv) Procedural security activities. (v) Reputational, legal and certain financial risk" [11]. These risk assessments were made by use of what Gully describes as a model which, "sets out the stages of a risk assessment in accordance with ISO 31000:2009” [12].

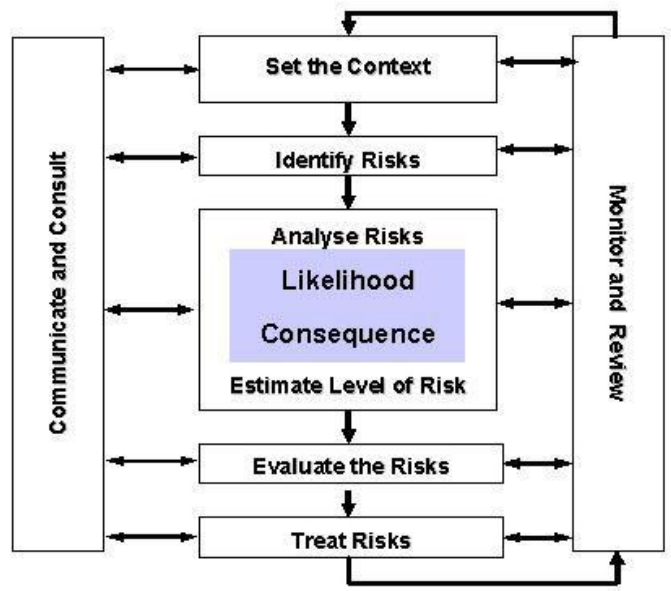

Figure 2: Principles of Risk Management (Gully, 2016, p.4)

With this procedural map, Gully then says that PNGUoT needs to: 1. "[Establish] the Business and Study Objectives"; 2 . "Undertake Stakeholder analysis";3. "Determine Critical Success Factors"; 4 . Determine the key elements; and,5. "Determine Risk Analysis Criteria". Only when this is done, in light of the stated vision and mission of the University, can an accurate and applicable risk assessment be made [13].

Once these five steps were performed, a risk matrix table (corresponding to ISO 31000:2014 standard) was created by Gully for PNGUoT management, which "correlates risks identified with severity of the risk and the likelihood and then scores that risk. A high score indicates something quite dangerous and a low score indicates a minor matter. Scores of 18 to 25 indicate an Extreme risk, 11 to 17 a High risk, 6 to $10 \mathrm{a}$ moderate risk and 1 to 5 a low risk" [14].

\subsection{Risk Assessment Results}

In all, 18 high-risk, serious occurrences were identified by Gully, namely: 1 . "Students take control of university"; 2. "Staff ambushed/Robbed travelling to University by road"; 3. "Robbery of Academic staff or students within campus"; 4. "Students commit crimes against each other or University whilst affected by drugs or alcohol"; 5. "Students use weapons to carry out attacks on other students following an escalation in tensions"; 6 . 
"Break and enter committed on dormitories/staff accommodation or facilities"; 7. "Local settlers claim parts of the University campus as their own and demand compensation for removal of food gardens"; 8. "Influenza/Cholera or other disease spread from local area persons to university"; 9. "Escalating crime and violence in region affects the university"; 10."Academic staff Assaulted/Intimidated"; 11. "Criminals employed within work force who exploit opportunities to commit crime"; 12. "Security Officers break the law or commit human rights breach"; 13. "Expatriate or senior national staff is kidnapped and held for Ransom"; 14. "Medical Facility Swamped"; 15. "Security Officer ambushed and robbed"; 16. "Medical or Security emergency exacerbated by evacuation Difficulties"; 17. "Small arson or electrical fire gets out of control"; 18 . "Essential Utility destroyed by persons wanting to close down facility" [15].

\subsection{Gully's Policy/ Procedure Recommendations}

Gully then did an assessment of the University's capacity to deal with these 'likely' and 'serious.' The worrying result was that of the 18 identified high-risk and most serious security threats, the University's capacity to respond in 14 of the cases was judged to be "ineffective" and the balance were judged as only "partially effective" [16]. He then detailed a number of "treatment options" to improve these responses [17]. Now, authors Sali and Betasolo, members of the University's Security Committee, will detail recent efforts of the University senior management and community to meet the security challenges Gully had ably described.

\section{University Responses to the Identified Security Risks}

The University's responses to Gully's recommendations can be classed as: 1 . Policy Responses and, 2. Procedural Responses. They can then be further classed as University management responses and
University community responses.

\subsection{Policy Responses: University Management}

The University's security issues are addressed through the following establishments with their specific functions: (1) The University Security Force: The force is responsible for the overall coordination of the security on campus. The Security Manager, who is accountable to the University Management through the Pro Vice Chancellor (Administration) manages a total of 80 manpower for the security operations at campus to maintain peace, law and order [18]; (2) The University Security Committee: The committee; which is made up of members selected from the security force, students services, buildings and estates, citizen and non-citizen associations and academics; plays a critical role in discussing key security issues in the campus and makes recommendation to the University Management through the Pro Vice Chancellor (Administration); (3) The University Disciplinary Committee: This committee, which is made of academics, non-academics and students, is an important committee tasked with determining their guilt or innocence when the students break a University Rule. This committee also reports to the University Management through the Pro-Vice Chancellor (Administration); (4) The University Students Services. This group, although is responsible for the overall students' welfare on campus, they make sure that security of the students are protected and they (students) do not break the University rules [19].

\subsection{Policy Responses: University Community}

The policy responses of the University community include: (1) The University Neighbourhood Watch Program (UNWP); (2) Community Relations with the Neighbours. (1) The UNWP is coordinated by the University Security Committee with regular reporting to the University Management via the Pro Vice Chancellor 
(Administration). This is actually about neighbours helping neighbours within the University residential areas. They are extra eyes and ears for reporting crime and helping neighbours. Members meet their neighbours, learn how to make their homes more secure, watch out for each other and report activity that raises their suspicions to the University Security Office [20]. This provides opportunity for neighbours to help each other when attacked by rogues. The Security Committee has identified key zone leaders who will direct and provide leadership in this important program at each zone in the residential areas. All residential members are expected to cooperate with each zone leaders.

(2) Community Relations with the Neighbours is another initiative of the University where University Security Officers and students visit the neighbours and address to them about the need for the University and the neighbouring settlements to live with common understanding and a sense of respect [21].

\subsection{Procedural Responses: University Management}

The procedural responses of the University management include: Erecting security Fence; 24-Hour manning and maintenance of the security gate; Zero tolerance on alcohol and drug abuse; and regular security patrols. Such procedures are held to be effective in meeting the specific security challenges of PNG, as noted by Garry Sali [22].

The Security Officer at the time, Mr. Alex Warren and team, identified three (3) high risk areas in the University as follows: Hotspot 1 is Finishtere Road Between Catholic Church and 6 - Kona Flats; Hotspot 2 is Sarawaged Road between Markham Place and Sogeri Market (drainage and the downline fencing) and Hotspot 3 is at Back track near Rainforest Habitat fencing line as shown in the map [23].

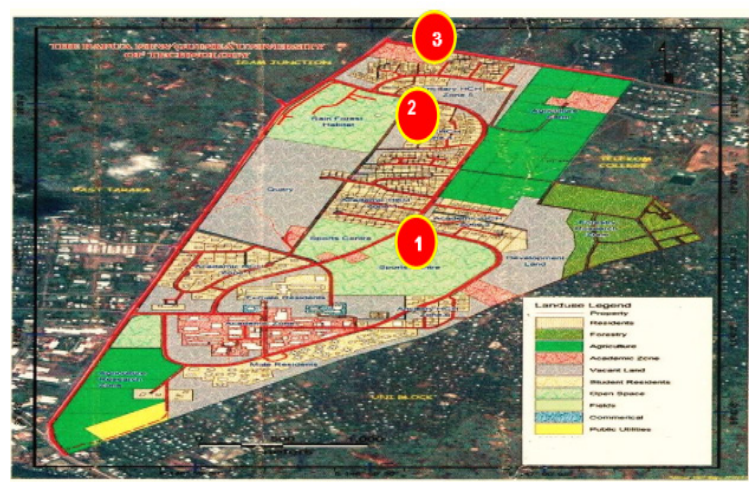

Figure 3: Crime hotspot areas on UNITECH campus (Warren, et. al., 2018)

Records for 2017- 2018 incidents on the different hotspots are: Hotspot 1 had 7 reported incident, Hotspot 2 had 12 incidents (which Markham Place ranked the highest with 7 crimes), and Hotspot 3 had 3 incidents. The quantitative results on forecasting for crimes to happen again to Markham Place, chosen location for the analysis because it has the highest record of incident, that there are at least 3 incidents to happen (as shown in the figure, QM for windows, a software that analyze quantitative methods), which as of this writing already had incidents of more than 3 in four months time [24].

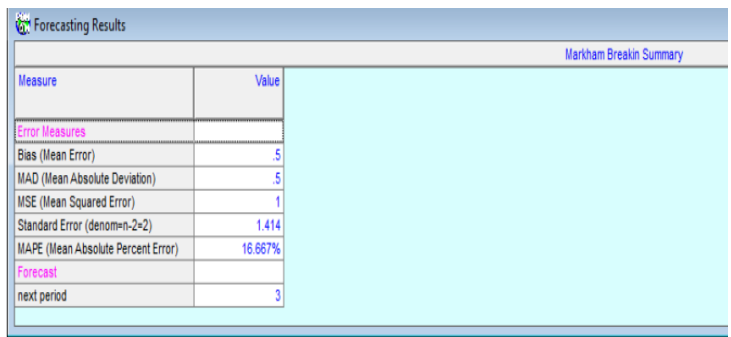

Figure 4: Forecasting analysis using QM for Windows on crime occurrences at Markham Place, Unitech (Warren, et. al., 2018)

The security manpower used in the analysis of allocating these men, using a quantitative approach. Assignment (with moving average) that maximizes the manpower allocation on the 3 areas that are Hotspots. There were 3 guards assigned in Hotspot 1 and the QM analysis shows that the current guard posting is adequate with average patrol timing of 40 minutes. Markham 
Place analysis (7/12 crimes) shows that it is insufficient with 2 on patrol moving from Sogeri, Bagana Mare and Markham Place at an average of 20 minutes. An additional 2 additional guards are required at Hotspot 2, with at least 1 static guard stationed at Markham Place, while others are moving on a 40 minute patrol. There are currently 3 allocated guards on patrol at Hotspot 3, which is sufficient based on the QM for Windows software.

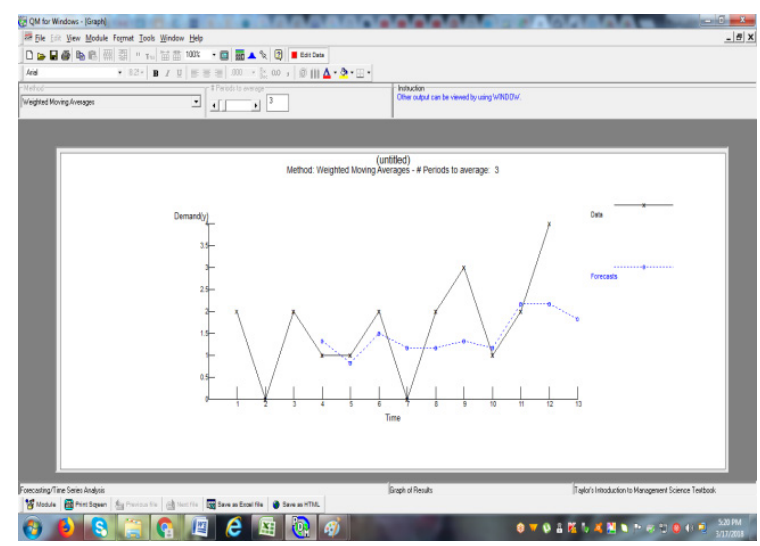

Figure 5: Reduced crime analysis of measures for additional manpower as made on QM for Windows (Warren, et. al., 2018)

The team reported that during the holiday season (December - January) number of manpower should be increased as more crimes on these periods were committed. The team further recommended to provide logistical support (vehicles around fence line, rain coats, gum boots), improve infrastructure (security lights, and fencing), and create a harmonious relationship with the nearby settlers as part of the University Corporate and Social Responsibility) [25].

\subsection{Procedural Responses: University Community}

Though the University Neighbourhood Watch Program (UNWP) is coordinated by the University Security Committee, the University Security Force plays a pivotal coordination role. The community members are expected to report any crime or suspicious criminal behaviour to the security office's dedicated security emergency mobile number. The University community is divided into 23 zones and zone leaders have been appointed. The zone leaders conduct zone meetings with zone members who have explained to the residents what they are expected to do in this program; Report suspicious activities and crimes to the University Security Office.

The Community relations aspect of security response requires a careful selection of few security officers and students who are knowledgeable about the surrounding community. They must be very selective with their words on what and how they address the community. Usually, the first contact with the landlord is key to the success of the program. There have been few times the University has conducted awareness on the need to respect the rule of law and have mutual respect for their existence [26].

\section{Conclusions}

Over the five decades of its operation on its Lae campus, PNGUoT/UNITECH has faced varied and, in recent years, increased security challenges. With Gully's 2016 analysis to guide it, the University's administration and community have sought to undertake both policy and procedural updating to improve the security of students, staff and its host community. As noted in psychologist Albert Maslow's seminal work, security is one of the foundational needs of each student and staff member that must be met if his or her higher-level human functions (such as teaching and learning) are to be achieved [27]. As a Knowledge-Based-Organization dedicated to producing employable graduates for sustaining PNG's national development, we have every intention of making a secure and safe campus, following the plans articulated herein.

\section{Acknowledgements}

Thanks are due to colleagues at PNGUoT who freely shared their (sometimes unpleasant) security experiences with $\mathrm{Mr}$ 
G.G. Gully during his assessment visit, which occurred soon after the campus violence in June 2016 (22 July 2016). Author Gilder took part in the same debriefing as then-President of the Non-
Citizen Staff Association (NCSA), and thus one of a number of on-campus "Risk Assessors".

\section{References}

[1] Central Intelligence Agency. The World Factbook, East Asia/Southeast Asia: Papua New Guinea. Washington, D.C. [USA], March 21, 2019. Retrieved: https://www.cia.gov/library/publications/the-world-factbook/geos/pp.html (30/03/2019).

[2] Ibid.

[3] Central Intelligence Agency, op. cit.; Gully, G.G. University of Technology Risk Environment Statement, Forward (unpublished consulting report), 2016 (pp. i-ix).

[4] The Papua New Guinea University of Technology. Vision and Mission (n.d.). Retrieved: http://www.unitech.ac.pg/?q=unitech/vision (30/03/2019); Wikipedia, "Lae" 12 March 2019, Retrieved: https://en.wikipedia.org/wiki/Lae (30/03/2019).

[5] According to the CIA World Factbook (op. cit.), the balance of PNG population dispersion is: "urban population: $13.2 \%$ of total population (2018), rate of urbanization: $2.51 \%$ annual rate of change (2015-20 est.)".

[6] Ibid.

[7] Gully, G.G. University of Technology: Risk Environment Statement, Forward, p. ii, 2016.

[8] World Bank (IBRD/IDA). The Costs of Crime and Violence in Papua New Guinea, 15 August, 2014. Retrieved: http://www.worldbank.org/en/news/feature/2014/08/15/thecosts-of-crime-and-violence-in-papua-new-guinea (30/03/2019).

[9] See: Kehatsin, J. S. Unlocking Conflicts in the Public Universities in Papua New Guinea. Unpublished PhD thesis, Department of Communication and Development Studies, PNGUoT, December, 2016.

[10] Jackson, K. Student killed, buildings torched in savage Unitech attack. Keith Jackson \& Friends: $\quad P N G$ Attitude (Blog). 26 June, 2016. Retrieved: https://asopa.typepad.com/asopa people/2016/06/student-killed-buildings-torched-insavage-unitech-attack.html (30/03/2019); Betasolo, M.L. Culture - educational paradigm shift learning methodologies derived from axiomatic design principle, Procedia CIRP 53 (2016): 179-186. Retrieved: https://doi.org/10.1016/j.procir.2016.08.035 (01/4/2019).

[11] Gully, G.G. Unitech Security Risk Assessment \& Management Plan. (Unpublished consulting report), 2016 (pp. 1-32).

[12] Op cit., p. 5.

[13] Op cit., p. 6.

[14] Op cit., p. 13.

[15] Labelled "Table 6.1.1: Serious Risks", op cit., pp. 15-18

[16] Labelled "Table 7.1.1 Risk Analysis Results", op cit., pp. 19-20.

[17] Labelled "Table 9.3.1. Potential Treatment Options", op cit., pp. 23-30.

[18] University Security Committee Report/University Community Neighbourhood Watch Program Concept. (Unpublished internal document) PNGUoT, 2018.

[19] Ibid.

[20] Ibid.

[21] Ibid. 
[22] Sali, G. Papua New Guinea state university students in conflict with social morality and the rule of law, Korean Journal of Correctional Discourse 11(1) (2017): 237-277.

[23] Warren, A., Paul, G., Moya, M. \& Betasolo, M.L. Quantitative analysis on addressing crime, allocation of security manpower at hotspot areas. (Conference Paper, Global Virtual Conference in Civil Engineering [GVCCE 2018]), PNGUoT, Lae, 9-10 November 2018.

[24] Ibid.

[25] Ibid.

[26] University Security Committee Report/University Community Neighbourhood Watch Program Concept. (Unpublished internal document) PNGUoT, 2018.

[27] Maslow, A. H. A theory of human motivation, Psychological Review 50 (1943): 370396. Reposted (August 2000) in Classics in the History of Psychology: An internet resource (ISSN 1492-3713). Retrieved:

http://citeseerx.ist.psu.edu/viewdoc/download?doi=10.1.1.318.2317\&rep=rep1\&type $=p$ df $(03 / 04 / 2019)$. 